\title{
Henri BERGSON, Sur le pragmatisme de William James
}

ed. by S. Madelrieux, Paris, PUF, 2011

\section{Sarin Marchetti}

\section{(2) OpenEdition}

\section{Journals}

Electronic version

URL: http://journals.openedition.org/ejpap/806

DOI: $10.4000 /$ ejpap.806

ISSN: 2036-4091

Publisher

Associazione Pragma

Electronic reference

Sarin Marchetti, «Henri Bergson, Sur le pragmatisme de William James », European Journal of Pragmatism and American Philosophy [Online], IV - 1 | 2012, Online since 23 July 2012, connection on 24 September 2020. URL : http://journals.openedition.org/ejpap/806 ; DOI : https://doi.org/10.4000/ejpap.806

This text was automatically generated on 24 September 2020.

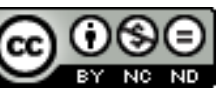

Author retains copyright and grants the European Journal of Pragmatism and American Philosophy right of first publication with the work simultaneously licensed under a Creative Commons AttributionNonCommercial-NoDerivatives 4.0 International License. 


\section{Henri BERGSON, Sur le pragmatisme de William James}

ed. by S. Madelrieux, Paris, PUF, 2011

\section{Sarin Marchetti}

\section{REFERENCES}

H. BERGSON, Sur le pragmatisme de William James, ed. by S. Madelrieux, Paris, PUF, 2011

1 This new volume of the first critical edition of Bergson's Oeuvres [2007-], directed by Frédéric Worms for the prestigious series Quadrige/Grand Textes of the Presses Universitaires de France, will be of particular interest for James' scholars. Stéphane Madelrieux, who assembled together and edited the materials included in the volume, offers us the whole body of Bergson's writings on James, and much more. In fact, besides the most famous introduction that le magicien Parisien wrote in 1911 for the Flammarion edition of Pragmatism, the volume comprises also other occasional pieces by Bergson, a selection of his letters to James, Abauzit and to some others fellow interlocutors, a few extracts from James' work that are often discussed in such commentaries and exchanges as well as some additional fragments focusing on Bergson's engagement with Le génie américain in the context of the early reception of his philosophy in France. All the writings are introduced, commented and annotated by Madelrieux, so that the reader is constantly accompanied throughout the dense and variegated pages of the book. In fact, despite the volume appears as an harmonious whole, the editor managed to arrange together a number of texts thought for rather disparate -and sometimes hardly comparable - audiences and circumstances. The task, far from being easy, is exquisitely accomplished. 
2 Some preliminary information on the book under consideration, given the complexity of its structure, is thus in need. The volume gathers together some materials already published by Bergson himself in his collection of writings La pensée et le mouvant [1934] which has been re-issued in the mentioned critical edition together with his earlier collection of essays L'énergie spirituelle [1919] -, plus other scattered pieces recently edited in a brand new volume titled Écrits philosophiques. And yet, as Worms writes in his avant-propos, given the importance and unity of some particular texts in Bergson's Oeuvres, PUF considered and finally decided to publish such materials as separated additional volumes. This happened not only to what became sur le pragmatisme de William James, but also to other individual texts we now have in a exclusive edition (for an up-to-date list of publications, as well as for more details on the whole project of the critical edition of his works, please do visit the website of the Bergson project at the following address:

[puf.com/wiki/Espace_Bergson/La_première_édition_critique_de_Bergson].

3 Madelrieux, in his Présentation, explains in detail the motives for such editorial choice and presents the quadripartite structure he gave to the volume, edited in accordance with the standards of the critical edition observed for the other volumes as well. The first part, titled Vérité et Réalité. Sur le Pragmatisme de William James, reproduces Bergson's renowned introduction to the first French translation of James' mature philosophical manifesto; the second part reprises all those occasional but not at all peripheral texts Bergson wrote (and, when not published himself, authorized for publication) on James; while the third consists in a selection of his letters to James, with the addition of a few letters to Abauzit regarding his (rather problematic) translation of Varieties of Religious Experiences. A fourth part, corresponding to the Dossier critique that closes the volume, besides containing some detailed notes to the previous texts, the index of the volume and a critical bibliography of the themes and figures discussed, includes another sequence of texts on and by James focused on his relationship with Bergson. Each of the four parts is singularly rich, and the editor greatly helps the reader with an introduction to both the first and the third, offering an even more detailed synopsis of each one of the texts appearing in the second and the fourth. Besides providing precious particulars on the vast materials presented, such series of introductions and notes trace a theoretical thread that is extremely interesting in itself. In the next few sections I shall try to assess such a thread and intertwine it with some considerations with which I myself have wrestled in my reading of James and Bergson. Far from being the only possible way to evaluate the volume, such a strategy allows me to blend together the historical documents reproduced with one contemporary speculative perspective through which we might read them, so to estimate the aging of the formers and the solidity of the latter. ${ }^{1}$

4 Adopting a mereological system of calculation, we may say that the figures of interest in the volume under examination are (at least) three: Bergson, James and their philosophical encounter(s). Each of them, with its dynamic character and ambiguous contours, partly overlaps with the others so that it is at times hard to trace down the multiple lines of contaminations and resistance between them. Madelrieux offers a key to make some order in this complexity. In the Présentation, spanning just six pages but 
of a rather impressive theoretical density, he argues for a line of investigation running through the writings gathered in the volume: namely, Bergson's interest for pragmatism as one aspect of a wider philosophical program that he finds in James' writings and that he himself sought to build into (and accomplish with) his work (xvii). ${ }^{2}$ This provocative proposal rules out (or, less dramatically, calls in question) from the very beginning two opposite but kindred interpretative tendencies: either that of claiming that Bergson and James, besides being after the same 'beast Intellectualism' - James' courtesy -, conducted their hunting with the very same philosophical strategies and weapons (it is significant to notice how some moments of their correspondence might convey precisely such an image); or that of claiming for the radical incompatibility of their assumptions, programs and even scopes (the last section of the forth part of the volume, titled Divergences et distorsions, collects two extracts by Kallen and Worms arguing for a version of this incompatibility account). Accordingly with this possible narrative the intellectual relationship between the two thinkers would be more nuanced and multi-faced than either a wholehearted convergence or an unbridgeable divergence, which had been variously advanced as the two main competing accounts in the past century of scholarship.

5 The alternative reading envisioned by Madelrieux complicates in an interesting way such two opposite strains of the received view of the James-Bergson affaire. In the first place it throws some light on more than one passage of the their correspondence as well as of the letters Bergson wrote to Ribot, Pitkin, Kallen and Delattre, where he addresses from different angles the origins and motives of his interest for some precise aspects of James' groundbreaking investigations. In fact, as the editor argues, in those texts Bergson claims more than once that his engagement with James sprang for a felt intellectual affinity with the way the American thinker depicted our mental life, and the variety of experiences animating it, in practical terms. In order to characterize such an engagement it thus results crucial to investigate the significance of Bergson's pronouncement about an harmonie préétablie $(33,75,78)$ with his American frère de pensée, together with his recurring remarks about the 'two different sources' of their thinking (19-20, 27, 32-3, 36, 72-3, 77, 151). In fact, especially in the exchanges with both his French and American interlocutors reproduced in the second part of the volume, we can appreciate a distinctive reaction by Bergson to versions of both (what we have labeled as) the convergence and the divergence accounts of his relationship with James: to those authors reducing his positions to the ones of James Bergson replies by showing the two different sources and starting points (psychological for James while exquisitely epistemological for him) of their respective philosophies, while to those readers stressing their differences Bergson responds by declaring his proximity to James' views on the nature of concepts and to the companion critique of traditional metaphysics. Such movements, rather than sheer inconsistency, reveal the complexity and multifariousness of Bergson's stance toward James. Furthermore, the relationship between the two had hardly been impermeable to their personal exchanges and encounters, and thus it is not unreasonable to think that Bergson's understanding and evaluation of James' philosophy - but the same could be said for James regarding Bergson's as well - evolved (if not changed) over time, so that those accounts taking in consideration only one occasion or stage of it cannot but result partial. Far from being a static record of assonances and divergences, the exchange between James and Bergson had been a vital confrontation not without turning points. In his précis to the texts appearing in the second part of the volume, Madelrieux registers such variations, 
while in his Introduction to the third part he stresses their significance for the understanding of some moments of their correspondence.

The harmonie prétablie with James of which Bergson writes to Horace Kallen and to James himself could thus be characterized as a convergence in views that however takes the form of an accord dans la difference (55). Bergson remarks how, notwithstanding his conversations with James were not free from disagreements and divergences, still their intellectual paths should be described as proceeding toward a shared goal, endorsing thus James' enthusiastic claim according to which the two were 'fighting the same fight.' Far from being one of unqualified support, their alliance resembles at times a virtuous circle of reciprocal critical inspiration - or, if you prefer an evolutionistic image, a symbiotic circle of mutual cooperation. In this context it results particularly significant what Bergson writes to Ribot in 1905 in order to characterize his engagement (at that point in time) with James, and in particular the professed similarities between some of their positions. He writes

[s]e reportant aux textes, on verrait sans peine que la description du stream of thought et la théorie de la "durée réelle" n'ont pas al même signification et ne peuvent se rattacher à la même origine. La première a une origine et une signification nettement psychologiques. La seconde consiste essentiellement en une critique de l'idée de temps homogéne, telle qu'on la trouve chez les philosophes et les mathématiciens. (19-20)

7 Being their meanings and points of departures different, the claimed harmonie of views is hence difficult to characterize, and yet still more valuable to investigate. It is Bergson himself to provide us a clue to proceed in such an inquiry. In fact, he concludes the letter to Ribot by voicing his own take on the relationship between the "philosophie française" as expressed in both his Essai sur les données immédiates and his Matière et Mémoire and the "psychologie américaine" as depicted in James' Principles of Psychology. He writes

[O]n pouvait partir de cette psychologie et l'élargir en philosophie: c'est si je ne me trompe, la marche qu'a suivie W. James. J'ai fait le chemin inverse. Approfondissant certains concepts philosophiques aux contours bien définis, je les ai vus se fondre en quelque chose de fuyant et de flou, qui s'est trouvé être du psychologique. (20)

This concise but telling characterization of the kind of relationship running between their respective intellectual projects sets the tone for what happened to become an intense collaboration in which the two sides progressively explored the conceptual regions surveyed by the fellow traveler. In fact, especially as their acquaintance and companionship intensified, the two authors sharpened their mutual readings, so that their felt reciprocal philosophical affinity soon grew into a structured commentary and use of the other's ideas. Their mounting friendship, far from impeding critical confrontation, represented an occasion for an even more serious study of each other's positions, so that as a matter of fact their exchanges were rarely free from painstaking examinations of their respective philosophical writings. James dedicated two texts to the analysis and valorization of Bergson's views, while Bergson, especially after James' death, had more than once the occasion to come back to his writings and ruminate about their significance. Bergson, in fact, not only welcomed James' pragmatism in its various articulations, but also spent significant energies in showing how its main tenets and consequences were functional to support some conclusions he himself was seeking to establish through his own work. It would thus be misleading to read Bergson's endorsement of James' project as a mere tribute paid to a close friend: what would be 
missed would in fact be the very possibility to understand his incursions into (and examinations of) such a project as lines of its possible development.

Madelrieux individuates in one of such incursions a key to read the material edited in the volume, inviting at the same time to reflect on the direction that some of the works of the two individual thinkers took as a result of their encounters. From the privileged viewpoint of a profound knowledge of the whole progress of their exchanges, in the Présentation he digs even deeper than Bergson in tracing the seeds of his interest and engagement with James, outlining an articulated narrative of such occasions. He writes

[D]eux ouvrages de James, antérieurs au Pragmatisme, ont contribué plus que les autres à déterminer la lecture que Bergson en a eue. Le premier est le grand traité de psychologie que James fait paraître en 1890, The Principles of Psychology. Il n'est pas étonnant que Bergson rende hommage aux "vues éblouissantes" que James a données de la vie intérieure, puisque la description du courant de conscience coïncide sur bien des points avec celle de la durée vraie qu'il avait présentée dans Les données immédiates [...] Il est néanmoins surprenant que jamais il ne rende hommage à un autre versant des Principles: non pas la psychologie introspective des données immédiates de la conscience, mais la psychologie naturaliste des fonctions mentales. Car c'est là qu'on trouverait sans doute l'origine de ce qu'il faut bien appeler un pragmatisme bergsonien, qui n'apparaîtra pleinement que quelques années plus tard avec Matière et mémoire [1896], dans la thèse centrale selon laquelle les fonctions mentales sont essentiellement tournées vers l'action, permettant une meilleure adaptation de l'individu à son environnement. Quoi qu'il en soit de ce silence, le livre de James devait convaincre Bergson que ce psychologue né avait, comme lui-même d'ailleurs, une aptitude unique à circuler parmi les âmes, comme aussi à aller et venir à l'intérieur d'elle-même. Ce don de la vision directe de l'esprit par l'esprit, que Bergson appela intuition, il devait en trouver la confirmation chez James dans un livre ultérieur, The Varieties of Religious Experience [1902]. Ce qui intéresse Bergson dans ce livre [...] [c'est] plutôt la valeur philosophique des expériences mystiques, [que permettre] de tirer des conclusions sur l'existence probable d'une source surnaturelle de ces états de conscience [...] C'est dire également l'importance qu'il allait donner aux expériences mystiques dans sa présentation du pragmatisme, pour faire valoir l'existence d'un autre type de vérité que les vérités utilitaires -pragmatiques- de l'intelligence. (xvii-xviii)

In this longish but seminal quotation Madelrieux makes the case for a precise strategy of en usage de James by Bergson that represents at the very same time an organic defense and valorization of his project. According to this narrative, Bergson drew an interesting path throughout James' works by connecting together several of its central aspects: namely, a naturalistic psychology of mental functions, a pragmatic approach to (both mental and worldly) reality, and a philosophical rehabilitation of mystical experiences. Being these the three axes along which James articulated his researches (psychology, philosophy and religion), according to Bergson their interplay reveals the overall trajectory and lasting significance of his pragmatic reconstruction in philosophy: namely, a re-evaluation of those provinces of experience that are often voided as spurious and thus removed from the philosophical attention (religious and mystical experiences being prominent among them). James' assertion according to which "it is the re-instatement of the vague [and inarticulate] to its proper place in our

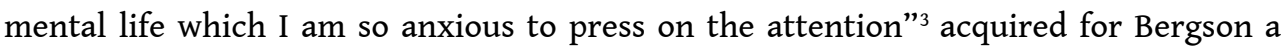
metaphysical as well as a moral significance, whose commitment took nothing less than 
the realization of his own philosophical system. In order to evaluate the soundness of Bergson's reading of James' pronouncement and his understanding of its underlying import, as well as the reconstruction of the two offered by Madelrieux, it would be pivotal to investigate at some more depth their main tenets and rationale.

11 According to this line of inquiry, the cornerstone of James' larger philosophical project would be his pragmatic conception of truth, that Bergson defends in the Préface to Pragmatism by offering a reading of it that stands in sharp opposition to the negative and often-ludicrous accounts gave by his fellow French commentators. ${ }^{4}$ Freeing James' characterization of truth from its misconceptions, a task which James himself found demanding when (and if) not appalling, ${ }^{5}$ represents in fact the first and foremost step to take in order to set the path of investigation of his work on the right track, and thus re-orientate the overall understanding of his pragmatism. As Madelrieux observes, not only Bergson fiercely rejects the accuses of skepticism and subjective relativism addressed to pragmatism by debunking the alleged jamesian 'scandalous identification' of truth with what is merely useful to believe, but also suggests how it is precisely a pragmatic approach to reality that allow us to treat properly those most important moral and spiritual aspects of our lives usually claimed by the detractors of pragmatism as lying beyond any consideration of utility, and thus unaccountable by it. Surprisingly enough the utilitaristic aspect of James' account of truth, according to which truths helps us coping with reality, becomes the key to analyze such most intimate aspects of our lives, since it would widen and enrich the whole range of our encounters with reality in which they find expression. Once characterized as an approach that not only welcomes but also exalts such personal and spiritual aspects of our lives, pragmatism would thus shrug off from its shoulders the label of a philosophy 'at the service of profit' and begin to appear as a genuine thinking that synthesize the best teachings of humanism and spiritualism. Usually resisted as somewhat superficial in its vulgar positivism, in Bergson's hands pragmatism becomes 'a doctrine porteuse d'une grande élévation morale' (xxvi, 13).

Far from being a vindication of some narrow theoretical technicality, according to Bergson James' pragmatic conception of truth unfolds an entire philosophical attitude (xxiii-xxix). Bergson was in fact one of the first to appreciate the wider significance of James' conception of truth, reading in his pragmatism much more than a skeptical variety of anti-philosophy. Such an overturning is of deep significance and has many articulations, and Bergson in his Préface explores with remarkable skillfulness one central line of such philosophical move that is of particular interest. By investigating James' conception of truth and reality, Bergson unravels what according to him are the real philosophical stakes of pragmatism: namely, a version of pluralism with deep leanings toward mysticism. Despite having the form of a generous homage to his cher James, this ambitious reconstruction was far from dispassionate. Bergson in fact stressed those very aspects of James' pragmatic account of truth that were functional to the defense of his own philosophical project of uniting empiricism and spiritualism. James' treatment of truth and reality would in fact provide both a refined conceptual tool to investigate such a possibility and a framework that makes hospitable his own philosophical intuitions about the nature of the mind and the world. Bergson's reading of James would thus be intrinsically intertwined with his use of James, since by 
advocating pragmatism he would be at the same time backing his own positions. This recurring dynamics may explain the somewhat surprising dialectic of his Préface to Pragmatism, where such an intertwinement takes one its clearer forms.

As Madelrieux notices, the introduction to Pragmatism has in fact a paradoxical character, since instead of presenting the contents of the book Bergson condenses a program for the reading of the entire James' oeuvre. However, the motives for such a choice are quite straightforward and promptly declared at the very outset of the essay: according to Bergson the misunderstandings of James' characterization of truth would be due to its having being read in isolation from the whole cluster of concepts presented in his other writings, generating in this way a distortions of its various dictates which lead to the condemnations of its main tenets (xxvi-xxvii, 93-4). Only by placing such characterization in a larger background it could be appreciated the richness of James' account of truth and thus acknowledged its strategic role for the attainment of what Madelrieux calls the 'spiritual realism' James - and Bergson after him - were so eager to establish (xxxii, 116). Written in 1911, Sur le pragmatisme de William James. Vérité et réalité waives together a great variety of themes taken from different moments of James' work (particularly his late writings on radical empiricism) and thus canvasses a suggestive overall picture of his pragmatism as animated by the interplay between a critique of the image of truth as copying and a companion refutation of a monistic conception of reality. Bergson opens his Préface by contending that it would in fact be erroneous - and hence deceptive - to analyze James' conception of truth in isolation from his companion characterization of reality, and presents the anti-intellectualistic motif of pragmatism as a consequence of the critique of the concept of experience as either a brute given or a hypostatization of a clear-cut abstract order. What would be missed in such accounts would be the active character of our experiencing and thus the open-ended nature of our practices of truth. Bergson writes

[D]e tout temps on a dit qu'il y a des vérités qui relèvent du sentiment autant que de la raison; et de tout temps aussi on a dit qu'à côté des vérités que nous trouvons faites il en est d'autres que nous aidons à se faire, qui dépendent en partie de notre volonté. Mais il faut remarquer que, chez James, cette idée prend une force et une signification nouvelles. Elle s'épanouit, grâce à la conception de la réalité qui est propre à cette philosophie, en une théorie générale de la vérité. (6)

Madelrieux registers in Bergson's text a tripartite characterization of James' pragmatic approach to both truth and reality as standing in opposition to those deterministic pictures of our life with experience. By disentangling in James' writings three theses (metaphysical, psychological and epistemological) on the nature of truth and reality Bergson would have shown how pragmatism is mostly apt to account for the indeterminate character of those experiences with which we perpetually engage in our ordinary praxes of worldmaking. Bergson, with James, would in fact be resisting those philosophies which, by pretending to keep thinking pure from life, alienate our expressive possibilities and discipline our most genuine encounters with the world after the needs and dictates of a reason depicted as having no regard for the very pluralistic character of reality (1-6). The will of which James, according to Bergson, speaks is not the purely instrumental will of the human being above reality, but rather it is the energetic will of the human being within reality; it is a will that augments the boundaries of reality by engaging with its wide-ranging contours and not a will that forces its limits by imposing its own alien dictates over it. 
15 It is in this context that Bergson reads in James' pragmatism a relentless attack to a well-established set of dualisms (rationality-sensibility, reason-will, intelligenceinstinct) deeply rooted in the history of western philosophy. ${ }^{6}$ Such dualisms would be superseded by the approach of the radical empiricist who is ready to admit the dynamic character of our experiencing and thus welcome those fringe aspects of reality exceeding our current and most celebrated scientific explanations - explanations which both thinkers aimed at enlarging rather than delegitimizing. In order to illustrate the wider significance of pragmatism as a kind of pluralism Bergson intertwines James' radical empiricism with the analysis of religious experiences canvassed in his 1901-02 Gifford Lectures The Varieties of Religious Experience [1902], which he reads as a defense of the philosophical credentials of religious and mystical experiences. Leaving aside the thorny issue of the relationship between pragmatism and radical empiricism, thorny for James' scholar but even thornier for Bergson himself due to his rather ambivalent attitude for some aspects of radical empiricism, what is worth noticing is the distinctive legacy Bergson envisions in James' account of truth. According to this view the truths that religious and mystical experiences convey to those who entertain them are no less grounded than the truths about physical bodies and their laws of gravitation that scientists ascertain through their experiments. As Bergson writes

[L]es sentiments puissants qui agitent l'âme à certain moments privilégiés sont des forces aussi réelles que celles dont s'occupe le physicien; l'homme ne les crée pas plus qu'il ne crée de la chaleur ou de la lumière [...] Les âmes que remplit l'enthousiasme religieux sont véritablement soulevées et transportées: comment ne nous feraient-elles pas prendre sur le vif, ainsi que dans une expérience scientifique, la force qui transporte et qui soulève? Là est sans doute l'origine, là est l'idée inspiratrice du "pragmatisme" de William James. Celles des vérités qu'il nous importe le plus de connaître sont, pour lui, des vérités qui ont été senties et vécues avant d'être pensées. (5-6)

16 Bergson reads in this affirmation the center of James' philosophical vision, and in the second part of his introductory essay (6-13) he presents the details of James' pragmatic conception of truth underpinning it. Bergson's emphasis on the pivotal role of truth for the understanding of James' pragmatism is more than well grounded. In fact it is James himself stating in 1907 (the year Pragmatism went in print) that "the theory of truth is the key to all rest of our positions,"7 and in particular those regarding the understanding of the statue, meaning and scope of moral and religious convictions which, because of their widespread pervasiveness in human affairs and the interest they exerted on him, James so often took as examples to illustrate the very gist of his pragmatism. ${ }^{8}$ Bergson takes at face value such statement and thus depicts an original account of James' conception of truth that vindicates its dictates. Madelrieux, in turn, reads in this move the seeds of the marriage of pragmatism (truth) with pluralism (reality-experience). In fact, following such a reconstruction, according to Bergson the conclusions about the pluralistic character of experience and reality at which James would arrive are nothing but a corollary of his pragmatic conception of truth, that in its turn cannot be understood independently from such conclusions.

17 According to Madelrieux, what makes this a virtuous, rather that a vicious, circle would be Bergson's characterization of the two axes of pragmatism and pluralism as connected with (and through) the third one of psychologism that Bergson, in his exchanges with Chevalier (47-9, 150-2), calls spiritualism. According to such third axe, whose pith is explored by James in his Principles of Psychology, being our mental constitution built as to form a stream of consciousness in which we subjects of 
experience are connected in a dynamic and practical way with its very objects, the truths which we predicate would be a function of our very attitude to reality. This antispectatorial picture of the mind would represents the backup for the pragmatist picture of truth animating Pragmatism, and reflects the two kinds of truths that Bergson reads in the text: respectively, artificial and spiritual truths (12). Both kinds of truths are grounded in reality, but while the former express our coping with reality with the purpose of achieving some artificial goals, the latter convey our penetration of reality with the purpose of achieving some goals that would exalt its inner and most intimate aspects. Madelrieux suggests to read such a depiction in the light of Bergson's indication of an analogous and related distinction, this time regarding the kind of access we have to our inner, as defended by James in the Principles. Bergson in fact individuates two different aspects or characterizations of psychological introspection (and of psychological inquiry tout court) pervading James' earlier and later writings: a scientific-like observation of the adaptation of one's faculties to the challenges of the environment, and a practical introspection which discloses our openness and engagement with the most spiritual aspects of ourselves and reality. It would be the presence of this latter practical introspection to secure the second type of truths, and thus rescue pragmatism from the charges of brute positivism.

\section{***}

It is worth pausing on this delicate passage, since from its validity it will depend the soundness of both Bergson's understanding of the wider significance of James' conception of truth and Madelrieux's account of it. I shall briefly advance two orders of considerations, one regarding Bergson's reading of James while the other regarding Madelrieux's evaluation of it, pointing to their respective strengths and weaknesses. Beginning with the latters, while agreeing with Madelrieux's overall articulated reconstruction of Bergson's interpretation of James' larger philosophical project, still I think that especially in the second part of his Préface (6-13) Bergson gives us a cutting presentation of some central ideas exposed in Pragmatism, as maybe no other commentator ever did, that do not find a proper presentation in Madelrieux's reconstruction. Bergson' account of James' conception of truth relies on a quantity of assumptions about the meaning and scope of pragmatism that are hardly undisputable, and still the Frenchman had some valuable insights about some of its most neglected aspects. Bergson was in fact among the firsts to appreciate James' realism, of which he both gave an interesting characterization and pictured as the key to interpret his entire work; still, I disagree with the peculiar use Bergson made of James' pragmatic conception of truth for the backing of his own (conceptually independent) philosophical project of a metaphysical pluralism, which Madelrieux accurately registers and endorses.

Regarding the strength of Bergson's reading of Pragmatism, its most interesting and precious insights lie in the characterization of James as a realist about truth $(75,81,93)$. Against the tide of criticisms raised against the alleged antirealism embedded in James' pragmatic refutation of truth as copying, Bergson stresses (and Madelrieux promptly acknowledges) a realistic motif running through the pages of the Préface (and, by Madelrieux, of the entire volume), which would commit James to a version of realism that is however critical of the correspondentist picture of agreement between true judgments and the reality they should account advanced by both scientific and 
metaphysical realism. As Bergson writes, for James truth is an invention, since the kind of agreement with reality it conveys is a practical one in which truths denote futureoriented leadings into reality that are worth while taking. According to James we in fact invent truths in order to engage with reality and thus, being so, such truths should necessarily be rooted in reality. Quoting Bergson's paraphrase of James, 'reality flows; we flow with it; and we call it true any affirmation which, in guiding us through moving reality, gives us a grip upon it and places us under more favorable conditions for acting.' This point, tirelessly stressed by James till his last breath, is used by Bergson to re-evaluate the wider significance of pragmatism for the issues of the philosophical feasibility of such non-scientific truths (and the realities they disclose) as religious ones. However, at this point Bergson makes a step James wouldn't have taken, since he creates a distinction within reality where James found none. According to James, in fact, all our truths are inventions and thus work in this way, and the distinctions we might be interested in making between different emphasis and nuances among different truth-judgments (and thus experiences) are themselves the outcome of our interests, and not derived from the properties of the very 'parcel of reality' as it might be seen from a view from nowhere. The active character of our stance toward reality governing our practices of truth causes all our encounters with the world being practical and inventive, and its various articulations mark no metaphysical, but only practical, possibilities within experience.

James' pragmatism could thus be labeled as a practical realism, its principle being, again with the words of Bergson, that "the true does not copy something which has been or which is: it announces what will be, or rather it prepares our action upon what is going to be. Philosophy has a natural tendency to have truth look backward: for James it looks ahead." This principles is of the utmost practical importance, since "our grammar would have been different, the articulation of our thought would have been other than what they are, had humanity in the course of its evolution preferred to adopt hypothesis of other kinds." Such quotations invite us to beware of the by-now customary charges of relativism, and rethink pragmatism as a version of realism alternative to both the copy-theory and metaphysical realism. This lesson, a variant of which was championed by Aristotle - or at least by some of his twentieth century readers -, should be handled with care, at risk of charging James with more than he himself envisioned for it and thus turning pragmatism into yet another metaphysical option that instead he was so keen to resist. Bergson, because of exigencies internal to his own philosophical system, turned James into a religious mystic by reading a metaphysical dichotomy where in his writings there was (only) a pragmatic distinction.

21 How (and why) Bergson does that is well depicted by Madelrieux, who accounts with great detail the seeds of such reading that he finds both appropriate and promising. Bergson reads in the Principles the conceptual seeds of a spiritualism claiming for a direct form of access to those spiritual realities animating experience through both a 'practical introspection' and a 'telepathic sympathy' that would put us in contact respectively with both ours fellow spirits and superiors ones. Accordingly to this reading, by picturing our mental functions as disclosing a Conscience supérieure governing the possibility of both the individuation of and the communication between souls James would have established a strong case for the possibility of a pansphychist account of reality. This way of uniting spiritualism and psychological descriptions, that Bergson articulated and developed in his own writings, seems to be suggested by James himself in some of his eclectic studies on the so-called "Exceptional Mental States,"9 
surfacing in many of his later writings as well. However, we might read the investigations of those mental states other than ordinary as simply unusual stances one might take on experience so to envision disregarded and distinctive possibilities of action, where for ordinary ones James would have classified those states of mind generating experiences that would raise no question about their justification of evidences (like those science uses to offer us). For James in fact spiritual energies or mystical experiences are valuable to postulate not because they allow us securing a more authentic contact with reality, but rather because they disclose and make us available genuine practical possibilities. That being so, their pragmatic value is of no categorical difference than those of what we usually call ordinary ones, and it can always be the case that what was considered at one stage a spiritual and exceptional truth might suddenly enter the vocabulary of the ordinary - and maybe even of the sciences -, or the other way around (as the history of ideas suggests).

Bergson's characterization of James as a pluralistic mystic thus stands in tension with a more viable image of his pragmatism as a wide naturalism: as James writes both in Pragmatism and in Varieties at greater length (lectures II and XX), religious experiences, instead of reveling another dimension of being, would be nothing but a living practical affair whose truths calls for a kind of engagement that is distinctive and compelling for those whose life is enlightened by them. James is neither arguing for the existence of two (or more) realities and hence of a (some) dichotomy(ies) within experience, nor trying to order them axiologically; rather, he is voicing a felt discomfort about the philosophical shrinkage of some provinces of experience at the expense of others. However, by opening the world indefinitely, and characterizing truth as standing for the various dynamic stances we might take toward reality, James was resisting precisely the temptation to advance any closed list of truths to which human beings ought to respond at pains of being lacking subjects of experience. A pragmatist progress would rather encourage us to explore ourselves those possibilities of experiencing that would fit at best our practical necessities without sublimating them into any higher region of being, thus violating the pragmatic maxim itself according to which the difference that makes a difference, instead of being univocal and theoretical, is always perspectival to, and practical for, those who are sensitive to it.

23 An alternative (although intertwined) path to the one sketched in the previous pages along which investigating Bergson's engagement with James, and thus assess the contents of the volume, is the theme of the relationship between biography and philosophy. Such a theme, pervasive as it is in both James and Bergson, finds an interesting articulation in their fashioning a philosophical friendship lasting eight years and a number of intense encounters, both live and written. Although I can merely point toward it, since its exhaustive examination would take as much space as the one already employed to sketch the one line actually chosen to pursue, such a path represents a very promising one due to the richness of its possible articulations. Its developments would have interested the commentary of those texts included in the volume where the theme of philosophical friendship surfaces in one of its multiple forms. The two major lines along which to articulate such an alternative investigation would be the philosophical characterization of the possibility to communicate intimate experiences -where such a communication is presented by Bergson as itself an 
experience of a spiritual kind -, and the description of such possibility as a practical challenge in which what is at stake is the capacity to establish a community of virtues between peers. Madelrieux explores aspects of such inquiries and presents some passages of their correspondence as illustrations of the intertwinement between a philosophical theorization of such concepts and their actual realization in a flesh-andblood philosophical friendship (xix, 37-43, 53-8).

As it has surfaced in section 3 of the present essay review, the two philosophers engaged in an intense reciprocal scrutiny and exploration whose dynamics embodies and at the same time puts on test - their respective philosophical conceptions about the unavoidable active and practical character of our encounters with the world and hence with the other fellow souls inhabiting it. Hardly any description could convey a better image of such a relationship, philosophical and intimate, than the words Bergson wrote to his student Chevalier, who in his turn canvassed a compelling portrait of his mentor's engagement with James in an essay written in occasion of the tricentennial of the foundation of Harvard University. Bergson writes

[V]ous montrez comment deux esprit partis de points différents, ayant suivi des chemins différents, doivent se rencontrer s'ils marchent l'un et l'autre dans la direction de la vérité. (45)

What is remarkable to stress is the very notion of heading dans la direction de la vérité: if, as James wrote (and Bergson subscribed), truth is "one species of good, and not, as is usually supposed, a category distinct from good and co-ordinate with it," ${ }^{10}$ than such deux esprits were proceeding a path that was worth while taking and exploring. A path at which us, their heirs and scholars, should look with extreme attention in our own philosophical as well as non-philosophical journeys.

\section{***}

The volume reviewed represents a precious tool for scholars of nineteenth and twentieth-century philosophy. The quality of its contents and the feature of their arrangement will be in fact of exceptional value for those interested in understanding such a seminal passage of the history of philosophy (and culture). Sur le pragmatisme de William James is a new book by Bergson, and as such us his contemporary readers should be grateful to the editor for his attentive and resourceful work. Forcing the temporal categories even further, had James the possibility of reading it he would have appreciated the thrilling intellectual activity generated by his encounter with Bergson, and, likely enough, he would have been as much fascinated as challenged by such a variety of possible interpretations of his own work.

\section{BIBLIOGRAPHY}

GAVIN W. J., (1992), William James and the Reinstatement of the Vague, Philadelphia, Temple University Press. 
JAMES H. Jr., (ed.) (1920), The Letters of William James, Boston, Atlantic Monthly Press, vol. 2.

JAMES W., (1983 [1890]), The Principles of Psychology, vol. 1, Cambridge, Harvard University Press.

JAMES W., (1975 [1909]), The Meaning of Truth, Cambridge, Harvard University Press.

MADELRIEUX S., (2008), L'attitude empiriste, Paris, PUF.

MADELRIEUX S. (ed), (2011), Bergson et James. Cent ans après, Paris, PUF.

TAYLOR E., (1984), William James on Exceptional Mental States: The 1896 Lowell Lectures, MA, University of Massachusetts Press.

\section{NOTES}

1. Regarding the latter assessment, I would like to mention two other works by the editor of the volume, one authored and one directed, in which lines of this reading are developed: S. Madelrieux (2008), L'attitude empiriste, Paris, PUF, (esp. chapters 2 and 8); id. (ed.), Bergson et James. Cent ans après, Paris, PUF, 2011 (esp. the Introduction by Madelrieux to his French translation of James' text Bradley ou Bergson?, and his essay De l'âme à l'inconscient. Métaphysique et psychologie chez James et Bergson).

2. Whenever not otherwise specified, all quotations are from the volume under review.

3. W. James (1983 [1890]), The Principles of Psychology, Cambridge, Harvard University Press, vol. 1, 246. The locus classicus of such program is ch. 9 on The Stream of Consciousness, from which the quotation is borrowed, even if the theme pervades the whole two volumes of the Principles as well as the later writings of James - which in fact can be (and have been) read as explorations of this theme in others philosophical domains. For an articulated treatment of the Jamesian pronouncement, see W. J. Gavin (1992), William James and the Reinstatement of the Vague, Philadelphia, Temple University Press.

4. Madelrieux includes in the Dossier critique of the volume an extract of a text by Françoise Mentré (139-42) that is representative of the widespread negative reception that pragmatism received in France. For more references to the context of James' early reception in France, see the Bibliographie spéciale that closes the volume (164-7).

5. A task to which he dedicated five intense years of his life, and whose most evident precipitate is the volume of essays The Meaning of Truth [1909]. As we can tell from the resigned tone of the last few lines of his Preface, hardly often such efforts had been rewarding for James, and likely enough the reading of Bergson's introductory essay would have mitigated his felt frustration for the 'inability almost pathetic' exhibited by some of his contenders 'to understand the thesis which they seek to refute' (Cambridge, Harvard University Press, 1975, 10).

6. It is nonetheless noteworthy to stress how, as Madelrieux himself notices (xxxvi-xxxviii), Bergson in his Préface uses at times a dualistic terminology that is however patently absent in Pragmatism (as well as in James' other writings), therefore forcing him in the very dualistic dialectic he was resisting by means of his radical empiricism. However, a similar criticism could be raised to Madelrieux's reconstruction as well, since in more than one passage he indulges in the very same dualistic terminology and dialectic, thereby acting as Bergson's accomplice although officially disguised as his commentator (xxxi, 111-2, 114-6).

7. H. James Jr. (ed.), (1920), The Letters of William James, vol. 2, Boston, Atlantic Monthly Press, 271.

8. The best exposition of this strategy can be found in the essay The Pragmatic Method. Published in The Journal of Philosophy, Psychology and Scientific Method in 1904, this text is a distillated of James' groundbreaking 1898 Philosophical Union of the University of California Address Philosophical Conceptions and Practical Results, and in my opinion it should be read as a 
prolegomena to both Varieties and Pragmatism, due to the clarity with which it depicts the way in which religious matters should be approached from the point of view of a pragmatist's conception of truth as leading.

9. See E. Taylor (1984), William James on Exceptional Mental States: The 1896 Lowell Lectures, MA, University of Massachusetts Press. For a detailed discussion of this aspect of James' work, see S. Madelrieux, L'attitude empiriste, cit., ch. 8-9).

10. W. James (1975 [1907]), Pragmatism, MA, Harvard University Press, 42.

\section{AUTHORS}

\section{SARIN MARCHETTI}

School of Philosophy, University College Dublin sarin.marchetti[at]ucd.ie 